\title{
EFFECT OF THERMAL MODIFICATION ON DECAY RESISTANCE OF CORYMBIA CITRIODORA AND PINUS TAEDA WOOD
}

\author{
Paes JB ${ }^{1}$, Brocco VF ${ }^{2}$ *, Loiola PL $^{3}$, Segundinho PGA $^{1}$, Silva $\mathrm{MR}^{4} \&$ Juizo CGF $^{5}$ \\ ${ }^{1}$ Department of Forest and Wood Science, Federal University of Espirito Santo, Governador Lindemberg, 316, 29550-000, \\ Jerônimo Monteiro, Espírito Santo, Brazil \\ ${ }^{2}$ Center for Higher Studies of Itacoatiara, Amazonas State University (CESIT/UEA), Avenida Mário Andreazza, São \\ Francisco, 69100-000, Itacoatiara, Amazonas, Brazil \\ ${ }^{3}$ Faber-Castell, Rua Piaui, 566, 38140-000, Prata, Minas Gerais, Brazil \\ ${ }^{4}$ Laboratory of Wood and Timber Structures, São Paulo University, Trabalhador São-carlense, 400, 13566-590, São \\ Carlos, São Paulo, Brazil \\ ${ }^{5}$ Instituto Superior Politécnico de Manica- ISPM, Vanduzi, Manica-Moçambique
}

*yfbrocco@hotmail.com

Submitted April 2020; accepted December 2020

\begin{abstract}
Alternative and eco-friendly technologies such as thermal modification can improve durability and dimensional stability of wood. This study evaluated the effect of thermal modification on resistance improvement of Corymbia citriodora and Pinus taeda wood against brown and white-rot fungi under laboratory conditions. Wood samples were subjected to treatment temperatures of $160,180,200,220$ and $240{ }^{\circ} \mathrm{C}$ in a laboratory electric furnace, under dynamic nitrogen atmosphere. A treatment temperature of $260{ }^{\circ} \mathrm{C}$ was additionally used for $P$. taeda. Seven planks, with dimensions of $6 \mathrm{~cm} \times 16 \mathrm{~cm} \times 56 \mathrm{~cm}$ (thickness $\times$ width $\times$ length), were used for each temperature. The thermally modified planks were transformed into prismatic test samples with dimensions of $1.9 \mathrm{~cm} \times 1.9 \mathrm{~cm} \times 1.9 \mathrm{~cm}$. Inoculated culture bottles containing test blocks were kept in an incubation room for 12 weeks. Thermal modification temperatures at 160 and $180{ }^{\circ} \mathrm{C}$ decreased the biological resistance of C. citriodora wood. Treatment temperatures of 200,220 and $240{ }^{\circ} \mathrm{C}$ showed satisfactory decay resistance gains for both species. Rhodonia placenta was the most degrading fungus at temperatures lower than $200{ }^{\circ} \mathrm{C}$.
\end{abstract}

Keywords: Biological resistance, thermally modified wood, wood-destroying fungi, brown-rot fungi, whiterot fungi

\section{INTRODUCTION}

Alternative technologies are able to change the chemical structure of wood and improve its biological resistance (Klüppel et al. 2015, Treu \& Larnøy 2016). Thermal modification has provided improved decay resistance, dimensional stability, weathering resistance, reduced water absorption, material darkening and colour stability (Silva et al. 2015, Sivrikaya et al. 2015, Pratiwi et al. 2019) in many species of wood.

Thermal treatment of wood emerged in European countries in the 1920s and have shown beneficial effects of the exposure of timber to temperatures close to $200{ }^{\circ} \mathrm{C}$ in dry or vapourised environments, with or without the use of nitrogen (Rapp \& Sailer 2001, MetsäKortelainen et al. 2006). In Brazil, the earliest studies of thermal treatment were conducted in the mid-1980s and the main method used commercially was the VAP HolzSysteme ${ }^{\circledR}$ (Batista et al. 2015, 2016). Changes in the wood chemical constituents improve biological resistance by reducing hemicellulose content, hygroscopicity and generating new toxic extractives (Sivrikaya et al. 2015). This process blocks the translocation of enzymes and hinders substrate recognition by fungi as food (Sivrikaya et al. 2015).

Intensity of the treatment that is characterised by thermal degradation (mass loss) is strongly correlated with the biological resistance of thermally modified wood, whereby the intensity of thermal treatment leads to an increase in loss of wood mass and decrease in weight loss by wood-destroying organisms (Candelier et al. 2016). However, depending on species of 
wood and process conditions, some results have reported limited improvement, or even loss of biological resistance, at treatment temperatures below $200{ }^{\circ} \mathrm{C}$ (Calonego et al. 2010, Paes et al. 2015, Batista et al. 2016, Candelier et al. 2016). This paper was aimed at evaluating the effects of different temperatures of thermal modification $\left(160,180,200,220\right.$, and $240{ }^{\circ} \mathrm{C}$ ) on the decay resistance of thermally modified Corymbia citriodora and Pinus taeda wood against brown-rot and white-rot fungi under laboratory conditions.

\section{MATERIALS AND METHODS}

\section{Materials}

The study materials were obtained from three 20-year-old pine and eucalypt. Pinus taeda trees came from the Jaguariaíva region, State of Paraná $\left(24^{\circ} 10^{\prime} \mathrm{S}, 49^{\circ} 20^{\prime} \mathrm{W}\right)$ and Corymbia citriodora, from the Brotas region, São Paulo, Brazil $\left(22^{\circ} 11^{\prime} \mathrm{S}, 48^{\circ} 05^{\prime} \mathrm{W}\right)$. The density values of fresh wood at $12 \%$ moisture content were 0.97 and $0.52 \mathrm{~g} \mathrm{~cm}^{-3}$ respectively.

Treatment was carried out at the University of São Paulo, Piracicaba, Brazil. Heartwood of $C$. citriodora and the outer sapwood of $P$. taeda were placed inside a metal box with lid, mounted one above the other in a vertical disposition. Nitrogen gas was injected inside the box during all thermal treatment, in order to avoid oxidation of the timber. Temperature control was monitored using seven type-K thermocouples, one installed inside the furnace, one in the metal box and five distributed on wood pieces.

The thermal modification process was done with an increase in furnace temperature from room temperature $\left(30{ }^{\circ} \mathrm{C}\right)$ until $100{ }^{\circ} \mathrm{C}$ for $40 \mathrm{~min}$. Afterwards, for each independent temperature, the heating rate used was $0.033^{\circ} \mathrm{C}$ $\min ^{-1}$ until the final temperature was achieved and kept for $120 \mathrm{~min}$ with a standard deviation of $\pm 5{ }^{\circ} \mathrm{C}$, totalling $33,43,53,63,73$ and 82 hours for treatment temperatures of 160, 180, 200, 220, 240 and $260{ }^{\circ} \mathrm{C}$ respectively. Seven planks, with dimensions of $6 \mathrm{~cm} \times 16 \mathrm{~cm} \times 56 \mathrm{~cm}$ (thickness $\times$ width $\times$ length) were used for each temperature. The thermal modification process is explained in Paes et al. $(2015,2016)$ and Silva et al. $(2013,2015)$.

\section{Decay resistance test}

Decay test was conducted according to ASTM D-1413 (2005a). To perform the test, prismatic samples with dimensions of $1.9 \mathrm{~cm} \times 1.9 \mathrm{~cm} \times$ $1.9 \mathrm{~cm}$ were taken from the thermally modified pieces and subjected to brown- (Gloeophyllum trabeum, Neolentinus lepideus, Rhodonia placenta) and white- (Trametes versicolor) rot fungi under laboratory conditions. A nutrient medium consisting of $2 \%$ malt extract and $1.5 \%$ agar (w:v) was used to prepare the Petri dish cultures of the test fungi. The assay was set up in $600 \mathrm{~mL}$ bottles filled with $300 \mathrm{~g}$ soil with a $\mathrm{pH}$ of 5.7 and $33.9 \%$ water holding capacity. The soil in each bottle was moistened at the water holding capacity, and two feeder strips of Pinus sp. wood (acquired from local commerce) were added to each bottle. The bottles were sterilised at $121 \pm 2{ }^{\circ} \mathrm{C}$ for $30 \mathrm{~min}$. After cooling the bottles, fragments obtained from pure cultures of the tested fungi were inoculated in the feeder strips. Two samples per bottle and 10 repetitions were used for each species and thermal modification temperature.

The test was kept in an incubation room $\left(25 \pm 2{ }^{\circ} \mathrm{C}\right.$ and $65 \pm 5 \%$ relative humidity) for 12 weeks. The samples were then dried under the same conditions as those used before the testing and mass loss was determined and evaluated by comparing the ASTM D-2017 (2005b) reference values for resistance. The natural resistance obtained at different treatment temperatures was compared with control samples $\left(100{ }^{\circ} \mathrm{C}\right.$, oven-dry condition for mass loss evaluation).

\section{Evaluation and analysis of the results}

A completely randomised design with a factorial arrangement was used to evaluate the natural resistance of thermally modified wood. The effect of temperature was tested separately for each species (six levels for Corymbia citriodora and seven for Pinus taeda) and fungus (four levels) using 10 repetitions for each situation. When necessary, to enable the normality of data (Lilliefors test), homogeneity of variances (Cochran's test) and statistical analyses, the values of percentage weight loss were

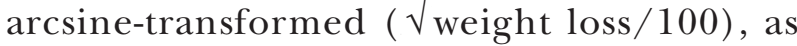
recommended by Steel and Torrie (1980). Tukey test $(\mathrm{p} \leq 0.05)$ was used for significant factors based on an F test $(\mathrm{p} \leq 0.05)$. 


\section{RESULTS AND DISCUSSION}

For the thermally modified C. citriodora and $P$. taed $a$ wood, the analysis of variance showed significant differences at the $1 \%$ level for wood mass loss of the evaluated fungi at different treatment temperatures and the interaction between the factors.

The means of the natural resistance of the control samples $\left(100^{\circ} \mathrm{C}\right)$, the wood of $C$. citriodora in contact with brown-rot ( $R$. placenta, G. trabeum and $N$. lepideus) and white-rot fungi (T. versicolor) did not differ between each other and were classified as highly resistant (Table 1). These results are consistent with those of Oliveira et al. (2005), who obtained mass loss values between 1.34 and $4.6 \%$ for the heartwood of the same wood species but subjected to G. trabeum fungal attack. Mass loss increased at 160 and $180{ }^{\circ} \mathrm{C}$, and a different behaviour between the fungi was observed (Table 1). Rhodonia placenta caused the greatest mass loss, and T. versicolor, in the treatment temperature of $180^{\circ} \mathrm{C}$, had the lowest mass loss. For other treatment temperatures, there was no difference in degradation of wood by the fungi. It is already well established that thermally modified wood will show improved biological durability (Calonego et al. 2010, Batista et al. 2015, Candelier et al. 2016), but a decrease at lower modification temperatures was observed in the present study.

Calonego et al. (2010) did not find any significant improvement in decay resistance of thermally modified Eucalyptus grandis wood at $140,160,180^{\circ} \mathrm{C}$. The decrease trend of decay resistance at lower temperatures of treatment was also reported by Paes et al. (2015, 2016) with termite test, where the temperatures of 160 and $180{ }^{\circ} \mathrm{C}$ led to decreased biological resistance. These findings corroborate the report by Candelier et al. (2016), whereby limited improvement in resistance was achieved against fungal decay for thermal treatment below $200^{\circ} \mathrm{C}$.

According to Silva et al. (2015), under treatment temperatures, volatile extractives were either evaporated or modified. However, there were no significant changes in the cell wall constituents and this might have facilitated the fungal attack.

Significant reductions in mass loss against fungal attack were observed only at temperatures of 220 and $240{ }^{\circ} \mathrm{C}$ compared with control samples. (Table 1). These treatment temperatures (220-
$240{ }^{\circ} \mathrm{C}$ ) caused major changes in chemical composition of the wood and, thus, food (hemicellulose) was not available for the fungi (Doi et al. 2005). Treatment temperature reduces equilibrium moisture content with the creation of new free molecules, which act as fungicides. Crosslinks of the lignin network hinder the fungus attack and reduce the degradability of wood (Doi et al. 2005).

Several studies have reported the benefits of thermal modification on the physical and colorimetric properties of C. citriodora wood (Silva et al. 2013, 2015, Delucis et al. 2014, Menezes et al. 2014, Santos et al. 2016). However, from the perspective of biological resistance gain, we do not think that the thermal modification of $C$ citriodora seems useful, since the wood showed high biological resistance.

Longer thermal treatment times used in the different treatment temperatures, mainly above $200{ }^{\circ} \mathrm{C}$, might also be a contributing factor to increased biological resistance. However, the impact of treatment temperature was reported to be stronger than the impact of treatment time on mass loss caused by fungal decay (Candelier et al. 2016). Pinus taeda was subjected to temperatures of 100,160 and $200{ }^{\circ} \mathrm{C}$, and had different mass loss among the tested fungi (Table 1). In control treatment $\left(100{ }^{\circ} \mathrm{C}\right), R$. placenta resulted in the greatest mass loss while $T$. versicolor, the least. This low mass loss in the control P. taeda wood was because white-rot fungi predominantly attacks hardwood and has less ability to attack softwood compared with brown-rot fungi (Zabel \& Morrell 1992, Schmidt 2006).

At treatment temperature of $180{ }^{\circ} \mathrm{C}$, $N$. lepideus caused the greatest mass loss, and T. versicolor caused the least amount of mass loss. The mass loss caused by R. placenta and G. trabeum was similar and lower than that of $N$. lepideus. At $220{ }^{\circ} \mathrm{C}$, the brown-rot fungi caused similar mass loss in the wood as at 240 and $260^{\circ} \mathrm{C}$, and there was no difference in deterioration between the brown- and white-rot fungi.

For $R$. placenta, there was an increase in resistance of pine wood at $180{ }^{\circ} \mathrm{C}$. Significant reductions in mass loss were observed for treatment temperatures of $220-260{ }^{\circ} \mathrm{C}$, which made the wood highly resistant to this fungus. A similar behaviour was observed for G. trabeum; in this case, the treatment temperature of $200{ }^{\circ} \mathrm{C}$ provided high resistance to the wood. For $N$. lepideus, increased resistance occurred after 
Table 1 Mass loss of Corymbia citriodora and Pinus taeda wood based on treatment temperatures and tested fungi.

\begin{tabular}{|c|c|c|c|c|}
\hline \multirow{2}{*}{$\begin{array}{l}\text { Temperature } \\
\left({ }^{\circ} \mathrm{C}\right)\end{array}$} & \multicolumn{4}{|c|}{ Mass loss $(\%)$ of Corymbia citriodora } \\
\hline & Rhodonia placenta & Gloeophyllum trabeum & Neolentinus lepideus & Trametes versicolor \\
\hline 100 & $\begin{array}{c}2.38 \mathrm{Ab} \\
\operatorname{HR}(0.33)\end{array}$ & $\begin{array}{c}2.19 \mathrm{Ab} \\
\operatorname{HR}(0.32)\end{array}$ & $\begin{array}{c}2.03 \mathrm{Ab} \\
\operatorname{HR}(0.44)\end{array}$ & $\begin{array}{c}2.41 \mathrm{Abc} \\
\operatorname{HR}(0.55)\end{array}$ \\
\hline 160 & $\begin{array}{c}6.35 \mathrm{Aa} \\
\operatorname{HR}(0.88)\end{array}$ & $\begin{array}{c}4.44 \mathrm{Ba} \\
\operatorname{HR}(1.15)\end{array}$ & $\begin{array}{c}4.84 \mathrm{Ba} \\
\mathrm{HR}(1.01)\end{array}$ & $\begin{array}{c}3.71 \mathrm{Ba} \\
\operatorname{HR}(0.69)\end{array}$ \\
\hline 180 & $\begin{array}{c}7.71 \mathrm{Aa} \\
\mathrm{HR}(2.93)\end{array}$ & $\begin{array}{c}4.68 \mathrm{Ba} \\
\operatorname{HR}(2.06)\end{array}$ & $\begin{array}{c}4.48 \mathrm{Ba} \\
\operatorname{HR}(1.21)\end{array}$ & $\begin{array}{c}2.76 \mathrm{Cab} \\
\operatorname{HR}(0.93)\end{array}$ \\
\hline 200 & $\begin{array}{c}1.90 \mathrm{Ab} \\
\mathrm{HR}(0.63)\end{array}$ & $\begin{array}{c}2.23 \mathrm{Ab} \\
\mathrm{HR}(0.65)\end{array}$ & $\begin{array}{c}1.59 \mathrm{Ab} \\
\operatorname{HR}(0.56)\end{array}$ & $\begin{array}{c}1.73 \mathrm{Ac} \\
\operatorname{HR}(0.82)\end{array}$ \\
\hline 220 & $\begin{array}{c}0.65 \mathrm{Ac} \\
\mathrm{HR}(0.17)\end{array}$ & $\begin{array}{c}0.77 \mathrm{Ac} \\
\operatorname{HR}(0.29)\end{array}$ & $\begin{array}{c}0.71 \mathrm{Ac} \\
\mathrm{HR}(0.16)\end{array}$ & $\begin{array}{c}0.57 \mathrm{Ad} \\
\operatorname{HR}(0.22)\end{array}$ \\
\hline 240 & $\begin{array}{c}0.45 \mathrm{Ac} \\
\operatorname{HR}(0.43)\end{array}$ & $\begin{array}{c}0.22 \mathrm{Ad} \\
\operatorname{HR}(0.15)\end{array}$ & $\begin{array}{c}0.41 \mathrm{Ac} \\
\operatorname{HR}(0.24)\end{array}$ & $\begin{array}{c}0.15 \mathrm{Ae} \\
\operatorname{HR}(0.12)\end{array}$ \\
\hline \multirow{2}{*}{$\begin{array}{l}\text { Temperature } \\
\left({ }^{\circ} \mathrm{C}\right)\end{array}$} & \multicolumn{4}{|c|}{ Mass loss (\%) of Pinus taeda } \\
\hline & Rhodonia placenta & Gloeophyllum trabeum & Neolentinus lepideus & Trametes versicolor \\
\hline 100 & $\begin{array}{c}61.50 \mathrm{Aa} \\
\mathrm{NR}(5.51)\end{array}$ & $\begin{array}{c}31.27 \mathrm{Ca} \\
\operatorname{MR}(6.77)\end{array}$ & $\begin{array}{r}47.91 \mathrm{Ba} \\
\mathrm{NR}(7.07)\end{array}$ & $\begin{array}{l}11.22 \mathrm{Da} \\
\mathrm{R}(2.89)\end{array}$ \\
\hline 160 & $\begin{array}{l}53.28 \mathrm{Aa} \\
\text { NR }(5.98)\end{array}$ & $\begin{array}{l}24.79 \mathrm{Cab} \\
\operatorname{MR}(6.35)\end{array}$ & $\begin{array}{c}44.77 \mathrm{Ba} \\
\mathrm{NR}(3.58)\end{array}$ & $\begin{array}{c}4.52 \mathrm{Db} \\
\operatorname{HR}(1.41)\end{array}$ \\
\hline 180 & $\begin{array}{c}42.30 \mathrm{Bb} \\
\operatorname{MR}(10.04)\end{array}$ & $\begin{array}{l}19.42 \mathrm{Bb} \\
\mathrm{R}(8.48)\end{array}$ & $\begin{array}{c}44.84 \mathrm{Aa} \\
\mathrm{NR}(3.49)\end{array}$ & $\begin{array}{c}3.53 \mathrm{Cb} \\
\operatorname{HR}(1.39)\end{array}$ \\
\hline 200 & $\begin{array}{l}23.59 \mathrm{Ac} \\
\mathrm{R}(10.21)\end{array}$ & $\begin{array}{c}8.01 \mathrm{Cc} \\
\mathrm{HR}(4.03)\end{array}$ & $\begin{array}{l}16.97 \mathrm{Bb} \\
\mathrm{R}(9.10)\end{array}$ & $\begin{array}{c}2.23 \mathrm{Dbc} \\
\operatorname{HR}(0.79)\end{array}$ \\
\hline 220 & $\begin{array}{c}4.36 \mathrm{Ad} \\
\mathrm{HR}(2.18)\end{array}$ & $\begin{array}{c}5.54 \text { Ac } \\
\operatorname{HR}(2.41)\end{array}$ & $\begin{array}{c}6.55 \mathrm{Ac} \\
\mathrm{HR}(4.88)\end{array}$ & $\begin{array}{c}0.78 \mathrm{Bcd} \\
\operatorname{HR}(0.46)\end{array}$ \\
\hline 240 & $\begin{array}{c}1.04 \mathrm{Ae} \\
\operatorname{HR}(0.49)\end{array}$ & $\begin{array}{c}1.03 \mathrm{Ad} \\
\operatorname{HR}(0.42)\end{array}$ & $\begin{array}{c}0.38 \mathrm{Ad} \\
\operatorname{HR}(0.29)\end{array}$ & $\begin{array}{c}0.57 \text { Acd } \\
\operatorname{HR}(0.41)\end{array}$ \\
\hline 260 & $\begin{array}{c}0.15 \mathrm{Ae} \\
\operatorname{HR}(0.21)\end{array}$ & $\begin{array}{c}0.01 \mathrm{Ad} \\
\operatorname{HR}(0.00)\end{array}$ & $\begin{array}{c}0.04 \mathrm{Ad} \\
\mathrm{HR}(0.29)\end{array}$ & $\begin{array}{c}0.15 \mathrm{Ad} \\
\operatorname{HR}(0.26)\end{array}$ \\
\hline
\end{tabular}

Means followed by the same uppercase (horizontally) or lowercase (vertically) letter do not differ at $\mathrm{p}>0.05$. Numbers in parentheses represent the standard deviation; NR, MR, R and HR = non-resistant, moderately resistant, resistant and highly resistant respectively

treatment at $200{ }^{\circ} \mathrm{C}$ or higher. Improved wood resistance was also observed for the whiterot fungus, which caused less wood mass loss compared with the brown-rot fungi. In this case, the biological resistance of wood was changed from resistant to highly resistant (Table 1).

A decreasing trend in mass loss was observed in the thermally modified $P$. taeda following fungi attack compared with control $\left(100^{\circ} \mathrm{C}\right)$. In general, pine wood was classified as resistant when treated at $200{ }^{\circ} \mathrm{C}$ and highly resistant at $220^{\circ} \mathrm{C}$ (Table 1). Mass loss less than 5\% was observed for Pinus radiata, Pinus sylvestris, Pseudotsuga menziesii and Picea abies after treatment at $220^{\circ} \mathrm{C}$ and exposed to $T$. versicolor (white-rot fungus) and Coniophora puteana (brown-rot fungus) (Militz \& Tjeerdsma 2001).

Momohara et al. (2003) observed that the minimum requirements to obtain significant improvements in the natural resistance of Cryptomeria japonica wood against Fomitopsis palustris was $135^{\circ} \mathrm{C}$ for 24 hours. Rapp and Sailer (2001) observed that the mass loss of P. sylvestris and $P$. abies that were not thermally modified were 48.0 and $40.0 \%$ respectively, for the fungus Coniophora puteana (brown rot). These same wood species, when thermally modified at 180 to $220{ }^{\circ} \mathrm{C}$ for 4.5 hours, showed mass losses of 
11.0 and $5.5 \%$ respectively (Rapp \& Sailer 2001). When the time and treatment temperature are increased, the resistance of the wood against decay increases (Momohara et al. 2003). This is due to the physical and chemical changes that occur in the wood during thermal modification, as discussed for the wood of C. citriodora.

\section{CONCLUSIONS}

Thermal modification temperatures at 160 and $180{ }^{\circ} \mathrm{C}$ decreased the biological resistance of C. citriodora wood. Rhodonia placenta was the fungus that most severely attacked treated wood at temperatures below $200{ }^{\circ} \mathrm{C}$. Treatment temperatures of 200,220 , and $240{ }^{\circ} \mathrm{C}$ promoted satisfactory decay resistance gains for C. citriodora and P. taeda.

\section{REFERENCES}

ASTM (American Society For Testing And Materials). 2005a. ASTM D-2017: Standard method of accelerated laboratory test of natural decay resistance of woods. Annual Book of ASTM Standard. ASTM, West Conshohocken.

ASTM. 2005b. ASTM D-1413: Standard test method for wood preservatives by laboratory soil-block cultures. Annual Book of ASTM Standard. ASTM, West Conshohocken.

Batista DC, Nisgoski S, Oliveira JTS, Muñiz GIB \& Paes JB. 2016. Resistance of thermally-modified Eucalyptus grandis W. Hill ex Maiden wood to deterioration by dry-wood termites (Cryptotermes sp.). Ciência Florestal 26: 671-678. doi:10.5902/1980509822766

Batista DC, Paes JB, Muñiz GIB, Nisgoski S \& Oliveira JTS. 2015. Microstructural aspects of thermallymodified Eucalyptus grandis wood. Maderas. Ciencia y tecnologia 17: 525-532. doi: 10.4067/S0718221X2015005000047

Calonego FW, Severo ETD \& Furtado EL. 2010. Decay resistance of thermally-modified Eucalyptus grandis wood at $140^{\circ} \mathrm{C}, 160^{\circ} \mathrm{C}, 180^{\circ} \mathrm{C}, 200^{\circ} \mathrm{C}$ and $220^{\circ} \mathrm{C}$. Bioresource Technology 101: 9391-9394. doi:10.1016/j. biortech.2010.06.119

Candelier K, Thevenon M-F, Petrissans A, Dumarcay S, Gerardin P \& Petrissans M. 2016. Control of wood thermal treatment and its effects on decay resistance: a review. Annals of Forest Science 73: 571-583. doi:10.1007/s13595-016-0541-x

Delucis RA, Gatto DA, Cademartori PHG, Missio AL \& SCHneId E. 2014. Physical properties of four thermally treated hardwoods. Floresta e Ambiente 21: 99-107. doi:10.4322/floram.2014.008

Dor S, Aoyama M, Yamauchi S \& Kurimoto Y. 2005. Changes of decay and termite durability of Japanese larch (Larix leptolepis) wood due to high-temperature kiln drying process. Journal of Wood Science 51: 526-530. doi: 10.1007/s10086-004-0684-5
Klüppel A, Cragg SM, Militz H \& Mai C. 2015. Resistance of modified wood to marine borers. International Biodeterioration and Biodegradation 104: 8-14. doi:10.1016/j.ibiod.2015.05.013

Menezes WM, Santini EJ, Souza JT, Gatto DA \& Haselein CR. 2014. Thermal modification on the physical properties of wood. Ciência Rural 44: 1019-1024. doi:10.1590/S0103-84782014000600011

Metsä-Kortelainen S, Anitikainen T \& Vittaniemi P. 2006. The water absorption of sapwood and heartwood of Scots pines and Norway spruce heat-treated at $170{ }^{\circ} \mathrm{C}$. 64 : 192-197. doi: 10.1007/s00107-005-0063-y

Militz H \& TJeerdsma B. 2001. Heat treatment of wood by the PLATO-process. Pp 25-35 in Rapp AO (ed) Proceedings of Special Seminar: Review on Heat Treatments of Wood. 9 February 2001, Antibes.

Momohara I, Ohmura W, Kato H \& Kubojima Y. 2003. Effect of high temperature treatment on wood durability against the brown-rot fungus, Fomitopsis palustris, and the termite, Coptotermes formosanus. Pp 284-287 in Proceedings of the 8th International IUFRO Wood Drying Conference. 24-29 August 2003, Brasov.

Oliveira JTS, Tomazello M \& Silva JC. 2005. Natural resistance of seven eucalypt wood species to decay. Revista Árvore 29: 993-998. doi: 10.1590/S010067622005000600019

Paes JB, Segundinho PGA, Euflosino Aer, Silva Mr, Calil Junior C \& OliveirA JGL. 2015. Resistance of thermally treated woods to Nasutitermes corniger in a food preference test. Madera y Bosques 21: 157-164.

Paes JB, Segundinho PGA, Euflosino AER, Silva Mr, Calil Junior C \& Christoforo AL. 2016. Biological resistance of thermally treated Corymbia citriodora (Hook.) K.D. Hill \& L.A.S. Johnson and Pinus taeda L. woods against xylophagous termites. Revista Árvore 40: 535-541. doi:10.1590/0100-67622016000300017

Pratiwi LA, Darmawan W, Priadi T et al. 2019. Characterization of thermally-modified short and long rotation teaks and the effects on coatings performance. Maderas. Ciencia y Tecnologia: 21: 209-222. http://dx.doi. org/10.4067/S0718-221X2019005000208

RAPP AO \& SAILER M. 2001. Oil heat treatment of wood in Germany: state of the art. Pp 45-62 in Rapp AO (ed) Proceedings of Special Seminar: Review on Heat Treatments of Wood. 9 February 2001, Antibes.

Santos PV, Silva MA, Dias Júnior AF, Carvalho AM \& Nascimento AM, 2016. Wood technological quality of Corymbia citriodora (Hook.) K.D. Hill \& L.A.S. Johnson submitted to heat treatment process. Scientia Forestalis 44: 343-350. doi:10.18671/scifor. v44n 110.07

Schmidt O. 2006. Wood and Tree Fungi: Biology, Damage, Protection, and Use. Springer-Verlag, Berlin.

Silva MR, Machado GO, Brito JO \& Calil Junior C. 2013. Strength and stiffness of thermally rectified eucalyptus wood under compression. Materials Research 16: 1077-1083. doi:10.1590/S151614392013005000086

Silva MR, Brito JO, Govone JS et al. 2015. Chemical and mechanical properties changes in Corymbia Citriodora wood submitted to heat treatment. International Journal of Materials Engineering 5: 98-104. doi:10.5923/j.ijme.20150504.04 
Sivrikaya H, Can A, Troya T \& Conde M. 2015. Comparative biological resistance of differently thermal modified wood species against decay fungi, Reticulitermes grassei and Hylotrupes bajulus. Maderas. Ciencia y Tecnologia 17: 559-570. doi:10.4067/S0718-221X2015005000050

Steel RGD \& Torrie JH. 1980. Principles and Procedures of Statistic: A Biometrical Approach. Mc-Graw Hill, New York.
Treu A \& LaRnøy E. 2016. Impact of a low pulsed electric field on the fungal degradation of wood in laboratory trials. International Biodeterioration and Biodegradation 114: 244-251. doi:10.1016/j.ibiod.2016.07.007

Zabel RA \& Morrell JJ. 1992. Wood Microbiology: Decay and Its Prevention. Academic Press, San Diego. 